\title{
Value of Endorectal Magnetic Resonance Imaging at $3 T$ for the Local Staging of Prostate Cancer
}

\section{Wertigkeit der 3-T-MRT zur Vorhersage eines kapselüberschreitenden Tumorwachtums beim Prostatakarzinom}

Authors

Affiliations
J. Otto ${ }^{1}$, G. Thörmer ${ }^{1}$, M. Seiwerts ${ }^{1}$, J. Fuchs ${ }^{1}$, N. Garnov¹, T. Franz ${ }^{2}$, L.-C. Horn ${ }^{3}$, M. H. Do², J.-U. Stolzenburg² ${ }^{2}$ T. Kahn' ${ }^{1}$, M. Moche ${ }^{1}$, H. Busse ${ }^{1}$

Department of Diagnostic and Interventional Radiology, Leipzig University Hospital

Department of Urology, Leipzig University Hospital

3 Institute of Pathology, University of Leipzig

\section{Key words \\ - MR imaging \\ - staging \\ - prostate \\ neoplasms}

received $\quad 8.4 .2013$

accepted $\quad 23.10 .2013$

Bibliography

Dol http://dx.doi.org/

10.1055/s-0033-1356186

Published online: 20.2.2014

Fortschr Röntgenstr 2014; 186:

795-802 @ Georg Thieme

Verlag KG Stuttgart · New York . ISSN 1438-9029

\section{Correspondence \\ Harald Busse, PhD}

Department of Diagnostic and Interventional Radiology,

Leipzig University Hospital

Liebigstraße 20

04103 Leipzig

Germany

Tel.: ++49/341/9717413

Fax: $++49 / 341 / 9717409$

harald.busse@

medizin.uni-leipzig.de

\section{Zusammenfassung}

$\nabla$

Ziel: Bestimmung der Wertigkeit der Magnetresonanztomografie (MRT) bei $3 \mathrm{~T}$ zur Differenzierung zwischen organbegrenztem und kapselüberschreitendem Tumorwachstum beim Prostatakarzinom (PCa). Material und Methoden: Bei 38 konsekutiven Patienten mit histologisch gesichertem PCa erfolgte eine multiparametrische 3-T-MRT-Untersuchung mit endorektaler Spule. Zwei Radiologen mit 9 (A) bzw. 4 (B) Jahren Erfahrung in abdomineller und urogenitaler MRT-Bildgebung bewerteten die bildmorphologische Erkennbarkeit einer Kapselüberschreitung (ECE) bzw. Samenblaseninfiltration (SVI). Als Referenz diente die intraoperative Schnellschnittdiagnostik in den sechs Regionen apikal, dorsolateral und harnblasennah, jeweils beidseits sowie die postoperative Aufarbeitung des Prostatektomie-Präparats und der Samenblasen.

Ergebnisse: Die histopathologische Auswertung ergab eine ECE in 15 von 222 Regionen (10 von 37 Patienten) und eine SVI in 8 von 74 Regionen (5 von 37 Patienten). Sensitivitäten, Spezifitäten und Genauigkeiten der Detektion einer ECE betrugen für Radiologe A/B 93\%/67\%, 92\%/95\% und $92 \% / 93 \%$ pro Region bzw. 90\%/80\%, 74\%/ $82 \%$ und $78 \% / 81 \%$ pro Patient. Die entsprechenden Werte für die SVI lagen bei 80\%/100\%, 96\%/ $99 \%$ und $95 \% / 97 \%$.

Schlussfolgerung: Die MRT der Prostata stellt eine zuverlässige, nicht-invasive Methode zum lokalen Staging beim PCa dar.

Kernaussagen:

- Die endorektale 3-T-MRT erreicht hohe Genauigkeiten beim lokalen Staging des Prostatakarzinoms.

- Die patientenbasierte Sensitivität zur Detektion eines extrakapsulären Tumorwachstums betrug $80 \%$ und höher.

- Die entsprechende Spezifität zur Detektion eines organüberschreitenden Tumorwachstums (pT3) war hoch.

\section{Abstract \\ $\nabla$}

Purpose: To assess the accuracy of endorectal $3 \mathrm{~T}$ magnetic resonance imaging (MRI) in detecting extracapsular extension (ECE) and seminal vesicle invasion (SVI) of prostate cancer (PCa).

Materials and Methods: 38 consecutive patients with biopsy-proven PCa underwent multiparametric endorectal MRI at $3 \mathrm{~T}$ prior to prostatectomy. Two readers (A with nine years of experience and $B$ with four) used established criteria for ECE and SVI to diagnose the extent of local disease in six regions (apical, dorsolateral, basal; left and right each) with the highest chance of ECE. The standard of reference was provided by intraoperative frozen section analysis and prostatectomy specimens.

Results: Histopathology revealed ECE in 15 of the 222 regions (10 of 37 patients) and SVI in 8 of 74 potential regions ( 5 of 37 patients). The sensitivity, specificity, and accuracy in detecting ECE for reader A/B were 93\%/67\%, 92\%/95\% and $92 \% / 93 \%$ per region and $90 \% / 80 \%, 74 \% / 82 \%$ and $78 \% / 81 \%$ per patient, respectively. The corresponding values for the detection of SVI were $80 \% / 100 \%, 96 \% / 99 \%$ and $95 \% / 97 \%$, respectively.

Conclusion: Endorectal 3 T MRI is a highly reliable noninvasive technique for the local staging of PCa. Key points:

- Endorectal 3 T MRI provided high accuracy for the local staging of prostate cancer.

- The sensitivity in detecting extracapsular tumor growth per patient was $80 \%$ or higher.

- The specificity in detecting extracapsular extension (pT3 stage) was good.

Citation Format:

- Otto J, Thörmer G, Seiwerts M etal. Value of Endorectal Magnetic Resonance Imaging at 3T for the Local Staging of Prostate Cancer. Fortschr Röntgenstr 2014; 186: 795-802 


\section{Introduction}

$\nabla$

Magnetic resonance imaging (MRI) is widely accepted as the most accurate noninvasive diagnostic tool for the local staging of prostate cancer (PCa) [1]. Different studies on the accuracy of 1.5 T MRI for the local staging of PCa have reported average specificities higher than $80 \%$. Some studies suggest that $1.5 \mathrm{~T}$ MRI with an endorectal coil can provide specificities of up to $99 \%$ in detecting extracapsular tumor growth (stage T3) of the disease [2]. On the other hand, the range of corresponding sensitivities, $14-94 \%$, is very broad with an average value around $60 \%[3,4]$. This finding may have limited the clinical use of $1.5 \mathrm{~T}$ MRI as a routine tool for staging, as previously remarked by Fütterer et al. [5].

The introduction of clinical 3 T MRI has led to a number of studies aiming to determine the value of $3 \mathrm{~T}$ imaging for PCa staging. The higher signal-to-noise ratio generally provides a better image quality and will potentially allow for more accurate staging. Some studies that have compared the use of a standard phasedarray coil at $3 \mathrm{~T}$ with that of an endorectal coil at $1.5 \mathrm{~T}$, however, have shown that the former imaging technique is not necessarily superior in terms of local staging accuracy $[6,7]$. Heijmink et al. have recently compared the use of phased-array and endorectal coils at $3 \mathrm{~T}$ and found that the latter seems to provide a clear benefit in terms of diagnostic image quality and staging accuracy [8]. It is presently difficult to assume an improved PCa staging accuracy for higher field strengths due to the very limited number of dedicated studies. Therefore, the aim of this study was to assess the sensitivity and specificity of an endorectal 3 T MRI examination in detecting extracapsular extension.

\section{Materials and Methods \\ $\nabla$}

\section{Patient characteristics}

After obtaining IRB approval, 38 consecutive patients (FebruaryJune 2010) with histologically confirmed PCa underwent endorectal $3 \mathrm{~T}$ prostate MRI prior to radical prostatectomy. All patients gave written informed consent. 37 of them (mean age 65 years, range 53 to 75 years) were analyzed retrospectively and one patient was excluded because his urinary bladder opening was resected without prostatectomy. The general exclusion criteria were contraindications to MRI (e.g., pacemaker or cerebral metal clips), gadolinium-based MR contrast agents or endorectal coil insertion (e.g., prior anorectal surgery, inflammatory bowel disease or high anal sphincter tension), as well as severe claustrophobia. The median prostate-specific antigen (PSA) level was $13.5 \mathrm{ng} / \mathrm{ml}$ (range $3.7-56 \mathrm{ng} / \mathrm{ml}$ ) and the median postoperative Gleason Score (GS) was 7.0 (range 6-9). MRI was performed 1-16 days (mean 1.9 days) before prostatectomy. The mean time between transrectal ultrasound (TRUS)-guided biopsy and MRI was 55 days (range 11-119 days) for all patients and 58 days (range 33 -114) for 10 patients with extracapsular extension. All patients underwent one TRUS-guided biopsy with a mean count of 11.6 (range 6 - 27) tissue samples and an average of 4.0 (range $1-12$ ) of them being positive for PCa. The mean time between TRUS-guided biopsy and surgery was 57.6 days (range 12 - 120 days) for 27 patients without ECE and 61.4 days (range 34-115 days) for 10 patients with ECE. Patients were subdivided into three groups with low, intermediate and higher risk according to the D'Amico criteria (GS $\leq 6$ and PSA $\leq 10 \mathrm{ng} / \mathrm{ml}$, $\mathrm{GS}=7$ and PSA $10-20 \mathrm{ng} / \mathrm{ml}$ and $\mathrm{GS} \geq 8$ or PSA $\geq 10 \mathrm{ng} / \mathrm{ml})$.

\section{MRI protocol}

MRI was performed in a $3 \mathrm{~T}$ MRI unit (Magnetom Trio, Siemens Healthcare, Erlangen, Germany) using the combination of pelvic phased-array and endorectal coils (eCoil, Medrad, Pittsburg, PA) for signal acquisition. The endorectal coil was filled with $30-40 \mathrm{ml}$ of perfluorocarbon solution (Perfluorooctyl bromide, ABCR GmbH, Karlsruhe, Germany) to minimize susceptibility artifacts. Before the examination, all patients received an intravenous injection of either $40 \mathrm{mg}$ butylscopolamine (Buscopan, Boehringer Ingelheim, Germany, in four patients) or $1 \mathrm{mg}$ glucagon (Glucagen, Nordisk, Gentofte, Denmark, in 34 patients) to reduce peristalsis. Fast T1-weighted (T1w) localizer images were used to confirm the correct position of the endorectal coil and to define transverse slices orthogonal to the prostatic urethra. Morphologic imaging included a T2-weighted (T2w) fast spin-echo sequence (in-plane resolution $\mathrm{IPR}=0.57 \times 0.57 \mathrm{~mm}^{2}$, repetition and echo time TR / TE $=4400-4600 / 126 \mathrm{~ms}$, slice thickness $\mathrm{ST}=3.0 \mathrm{~mm}$, slice gap $\mathrm{SG}=0.6 \mathrm{~mm}, 19-22$ slices, field of view $\mathrm{FOV}=110 \times 110 \mathrm{~mm}^{2}$, flip angle $\mathrm{FA}=120-135^{\circ}$ ) covering the whole prostate and the seminal vesicles in transverse, coronal and sagittal planes. Diffusion-weighted imaging was performed with a single-shot echo planar imaging sequence $\left(\mathrm{IPR}=1.0 \times 1.0 \mathrm{~mm}^{2}, \quad \mathrm{TR} / \mathrm{TE}=3000 / 85 \mathrm{~ms}, \quad \mathrm{ST}=3.0 \mathrm{~mm}\right.$, $\mathrm{SG}=0.6 \mathrm{~mm}, 19-22$ slices, $\mathrm{FOV}=250 \times 250 \mathrm{~mm}^{2}, \mathrm{FA}=90^{\circ}$ ) in transverse planes using $b$-values of $0,50,400$ and $800 \mathrm{sec} / \mathrm{mm}^{2}$. Spectroscopic imaging was performed using an established prostate protocol based on a combination of point-resolved spectroscopy volume localization and $3 \mathrm{D}$ chemical shift imaging covering the whole prostate in 8 slices [1]. Dynamic contrast-enhanced imaging (DCEI) was based on a transverse T1w sequence (20 time steps of $12 \mathrm{~s}$ each, IPR $=0.57 \times 0.57 \mathrm{~mm}^{2}$, TR / TE $=4.7 / 1.7 \mathrm{~ms}$, $\mathrm{ST}=3.0 \mathrm{~mm}, \quad \mathrm{SG}=0.6 \mathrm{~mm}, 19-22$ slices, $\mathrm{FOV}=110 \times 110 \mathrm{~mm}^{2}$, $\mathrm{FA}=14^{\circ}$ ) following bolus injection of $15-20 \mathrm{ml}$ of contrast agent (Dotarem, Guerbet, Paris, France).

\section{MRI evaluation}

All patients were evaluated by two readers who had full access to the image data on a conventional radiological workstation (SIENET MV 1000, Siemens, Erlangen, Germany). The readers were blinded to the individual serum level of PSA, GS and the results of the histopathologic TNM classification but knew that all subjects had biopsy-proven PCa. Both readers had only limited prior experience in endorectal MRI interpretation of the prostate at 3T: Reader A (M.S.), a radiology specialist with 9 years of experience in abdominal and genitourinary MR diagnostics had read 40 endorectal prostate MRI cases, while reader B (J.F.), a resident in radiology with 4 years of general MR experience, had read 15 such cases.

The presence of extracapsular extension (ECE) was based on five established T2w imaging criteria: 1 . asymmetry of the neurovascular bundle, 2. obliteration of the rectoprostatic angle, 3. irregular bulging of the prostatic contour, 4 . low signal intensity in the rectoprostatic fat, and 5. overt extracapsular cancer [9]. Infiltration of the prostate capsule was defined by a regularly delineated tumor contact with a length of at least $10 \mathrm{~mm}$, similar to the criteria reported by Yu et al. [10]. If such a tumor contact showed irregular delineations or signal defects of the prostate capsule, even without hypointense $\mathrm{T} 2 \mathrm{w}$ areas in the periprostatic fat or neurovascular bundles, this region was considered as extracapsular extension (ECE) [11]. Previously reported criteria in the literature were used to identify seminal vesicle invasion (SVI) and involved at least one of the following findings: disruption or loss 
of normal vesicle architecture, focal or diffuse areas of low signal intensity within the vesicles, asymmetric thickening or irregular shape of the vesicle wall as well as evident tumor at the prostate base extending into the seminal vesicles [12]. In addition, DWI and DCEI findings were used to rule out false-positive findings caused by hemorrhage or inflammation after TRUS-guided biopsy [1]. Hypointense T2w areas in the prostate or seminal vesicles in combination with high signal intensities in pre-contrast $\mathrm{T} 1 \mathrm{~W}$ images were associated with hemorrhage. Linear, wedge-shaped or hypointense prostate areas as well as wall thickening or hypointense lumina of the seminal vesicles on T2w without restricted diffusion or suspicious DCEI were regarded as (chronic) inflammation [12].

Image analysis was confined to six regions that are generally assumed to have the highest probability for ECE and SVI, namely the left and right sides of the apical, dorsolateral midgland and basal parts of the prostate ( $\bullet$ Fig. 1) [13]. The readers first decided for $(+)$ or against $(-)$ the presence of ECE and SVI. In the $\left(^{+}\right)$ case, they were further asked to rate the confidence level of the above criteria $(\mathrm{CL})$ on a five-point scale as clearly not applicable $(C L=1)$, probably not applicable $(C L=2)$, unclear $(C L=3)$, probably applicable $(\mathrm{CL}=4)$ and clearly applicable $(\mathrm{CL}=5)$.

\section{Histopathological work-up}

Immediately after surgical resection, the urologist inked the apical, dorsolateral midgland and basal portions of the prostate before sending it to the institutional pathology department. After separation and histological staining of the highlighted regions, frozen sections were intraoperatively analyzed by a senior pathologist (L.C.H. 13 years of experience in urogenital pathology) with respect to the status of the surgical margins. The remaining prostate sample was then processed according to a clinically established protocol [13]. This involved transverse, 4 to 5-mm thick step sections perpendicular to the prostatic urethra yielding about 10 tissue slices per prostate. Each slice was subdivided into four quarters resulting in approximately 40 sequentially labeled specimens per case. The final pathological report contained histological results of the analyses of both the fresh frozen samples (intraoperatively) as well as the prostatectomy specimens (postoperatively).

\section{Correlation between MRI and histopathology}

All intraoperative and postoperative histological results were used for radiologic-pathologic correlation. The results of the MRI-based reader ratings were compared to the histopathologic findings by a supervisor (J.O.), a resident in radiology with a total of 120 prostate MRI examinations, who was aware of all clinical data. The MRIbased reader findings were evaluated for each region where the pathologist identified extraprostatic extension. The MRI rating was counted as a true positive, if at least one of the CL was 4 or higher $(C L \geq 4)$, and as a false negative, if all scores were less than or equal to $3(\mathrm{CL} \leq 3)$. Suspicious regions with $\mathrm{CL} \geq 4$ and no histopathological correlate were not necessarily counted as a false positive, but double-checked by the supervisor regarding potential errors in spatial mapping caused by gland deformation, fixationrelated shrinkage and misaligned tissue slicing. Following the "alternative neighbor correction" described by Turkbey et al., successful tumor mapping was assumed if respective findings were observed within immediately adjacent "neighbor" regions [14]. An extracapsular extension to the right dorsolateral midgland, for example, might effectively belong to a histopathological ECE of the right basal sample. If the supervisor located the MRI focus very

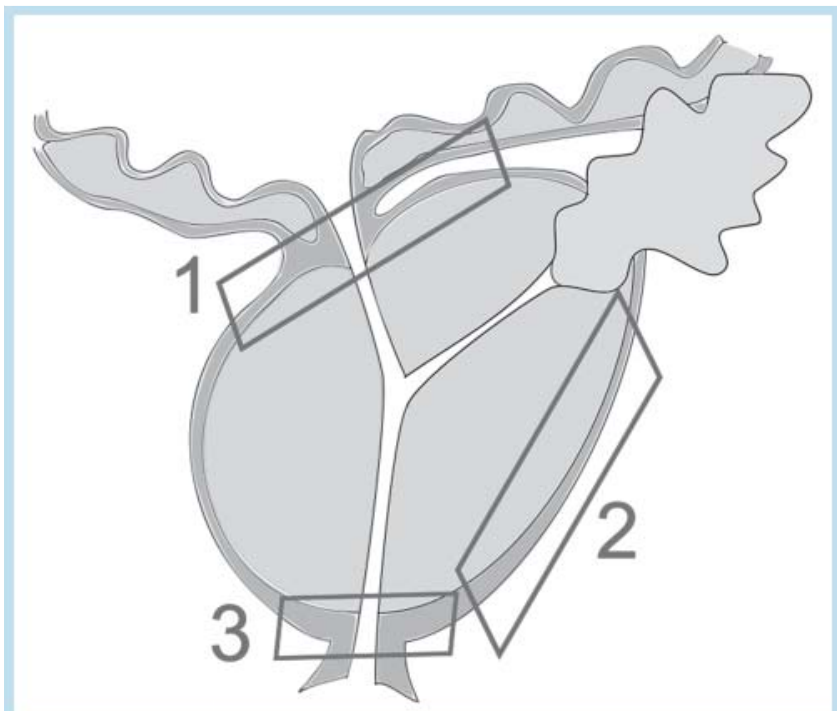

Fig. 1 Schematic sagittal cross section of the prostate gland showing the three (in total six for both sides) regions with the highest chance of ECE: basal (1), dorsolateral (2), and apical (3). These regions were all intraoperatively analyzed in frozen sections with respect to the status of surgical resection margins and the presence of extraprostatic extension.

Abb. 1 Schematischer Sagittalschnitt durch die Prostata mit Darstellung der drei (insgesamt sechs für beide Seiten) Regionen mit der höchsten Wahrscheinlichkeit eines kapselüberschreitenden Tumorwachstums: basal (1), dorsolateral (2) und apikal (3). Diese Regionen wurden alle intraoperativ mithilfe einer histopathologischen Schnellschnittdiagnostik zur Beurteilung des Resektionsrandes und dem Vorhandensein eines extrakapsulären Tumorwachstums untersucht.

close to the basolateral portion, which actually occurred in one case, the rating was still considered to be a true positive.

Differences in the preoperative staging performance between both readers were analyzed with a one-way ANOVA with factor reader. Statistical analyses were performed using SPSS 18 (SPSS Inc., Chicago, IL) and a significance level of $5 \%$.

\section{Results}

$\nabla$

Histopathology revealed extraprostatic extension into the periprostatic fatty tissue in 15 of the 222 (6.8\%) regions considered here (in 10 of 37 patients; $27 \%$ ) and into the seminal vesicles in 8 of the 74 potential regions (5 of 37 patients), respectively ( Fig. 2, 3, 4). The sensitivity, specificity, and accuracy in detecting ECE for reader A/B were $93 \% / 67 \%, 92 \% / 95 \%$ and $92 \% / 93 \%$ per region and $90 \% / 80 \%, 74 \% / 82 \%$ and $78 \% / 81 \%$ per patient, respectively ( $\bullet$ Table 1,2$)$. The corresponding values for the detection of a SVI were $80 \% / 100 \%, 96 \% / 99 \%$ and $95 \% / 97 \%$ for the respective reader ( Table 3,4 ). Table 5 summarizes the results of both uncorrected and alternative neighboring approaches. Differences between the readers were not significant, neither per region $(p=0.072)$ nor per patient $(p=0.556)$. Interobserver agreement $\mathrm{k}$ was 0.72 per region and 0.89 per patient. Histopathology revealed low, intermediate and high-risk PCa in 7, 19, and 11 of 37 patients with average PSA levels of 6.2, 8.4 and $28.8 \mathrm{ng} / \mathrm{ml}$ and median GS of 6 (no range), 7 (range $6-7$ ) and 8 (range 6-9), respectively. None of the low-risk $(0 \%)$, four 


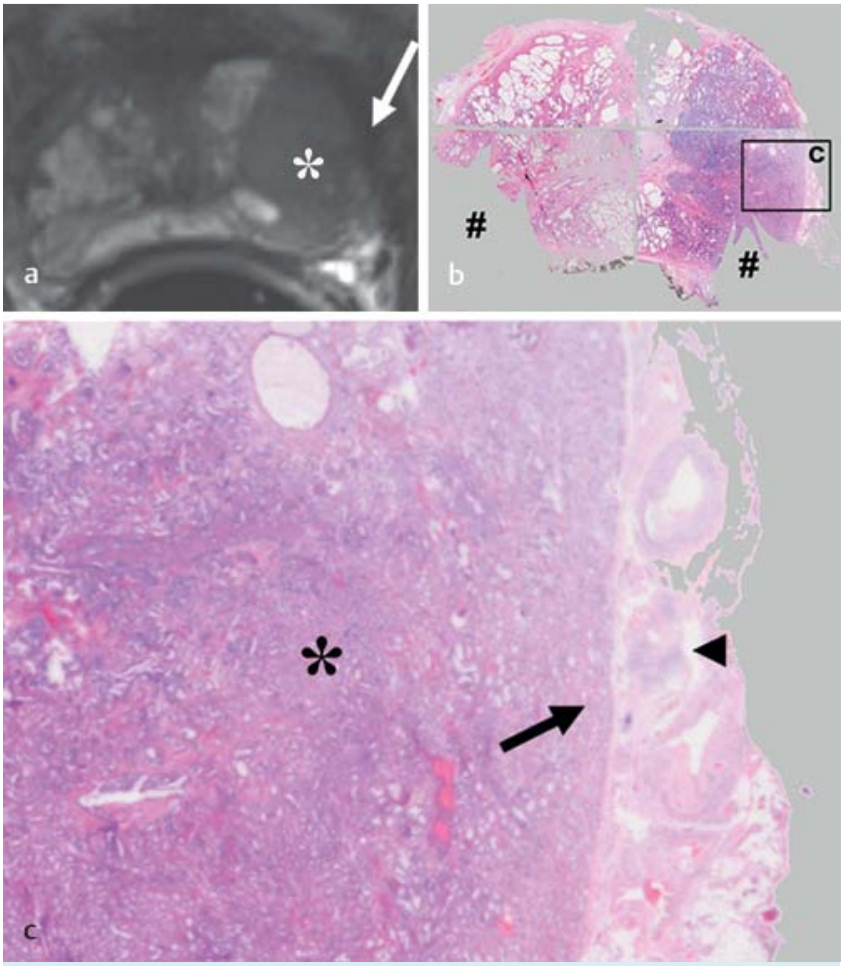

Fig. 2 73-year-old man with a PSA level of $10 \mathrm{ng} / \mathrm{ml}$ and GS $7(3+4)$ carcinoma. a: axial MRI with T2w hypointense mass (asterisk) in the left transitional and peripheral zone obscuring the prostate capsule with asymmetrical, irregular bulging of the prostate contour (arrow). b: corresponding reconstruction of perpendicular histological section of the specimen after radical prostatectomy. Dorsolateral edges (number) are missing because of prior frozen section analysis (see text and $\bullet$ Fig. 1) c: magnified area from b showing tumor cells (arrow head) in the periprostatic fat (stage PT3a) within a depth of less than $1 \mathrm{~mm}$.

Abb. 2 73-jähriger Mann mit PSA-Serumlevel von $10 \mathrm{ng} / \mathrm{ml}$ und GS 7 $(3+4)$ PCa. a: Axiales MRT mit Nachweis einer T2w-hypointensen Raumforderung (Sternchen) von Transitional- und peripherer Zone links mit vollständigem Kontakt zur Prostatakapsel und seitenasymmetrischer, irregulärer Vorwölbung der Prostata (Pfeil). b: Korrespondierendes histopathologisches Schnittpräparat nach radikaler Prostatektomie. Dorsolaterale Defektareale beidseits (Raute) aufgrund der intraoperativen Schnellschnittdiagnostik (siehe Text und $\bullet$ Abb. 1). c: Die Vergrößerung aus b zeigt Tumorzellen (Pfeilspitze) im periprostatischen Fettgewebe (pT3a Stadium) mit einer Infiltrationstiefe von weniger als $1 \mathrm{~mm}$.

Table 1 Extracapsular extension (ECE) of prostate cancer per individual region.

Tab. 1 Regionenbasierte Analyse eines extrakapsulären Tumorwachstums.

\begin{tabular}{llccccc} 
ECE per region & \multicolumn{2}{c}{ histopathology } & sensitivity & specificity & accuracy \\
\hline MRI & + & - & & & \\
reader A & + & 14 & 17 & $93 \%$ & $92 \%$ & $92 \%$ \\
& - & 1 & 190 & $(14 / 15)$ & $(190 / 207)$ & $(204 / 222)$ \\
\cline { 1 - 2 } reader B & + & 10 & 10 & $67 \%$ & $95 \%$ & $93 \%$ \\
& - & 5 & 197 & $(10 / 15)$ & $(197 / 207)$ & $(207 / 222)$ \\
\end{tabular}

(22.2\%) of the intermediate-risk, and six (54.5\%) of the high-risk group were found to have locally advanced disease.

The mean $\mathrm{CL}$ ratings of the individual ECE criteria (in parentheses) averaged over 15 regions for reader A/B were 2.5/2.0 (asym-
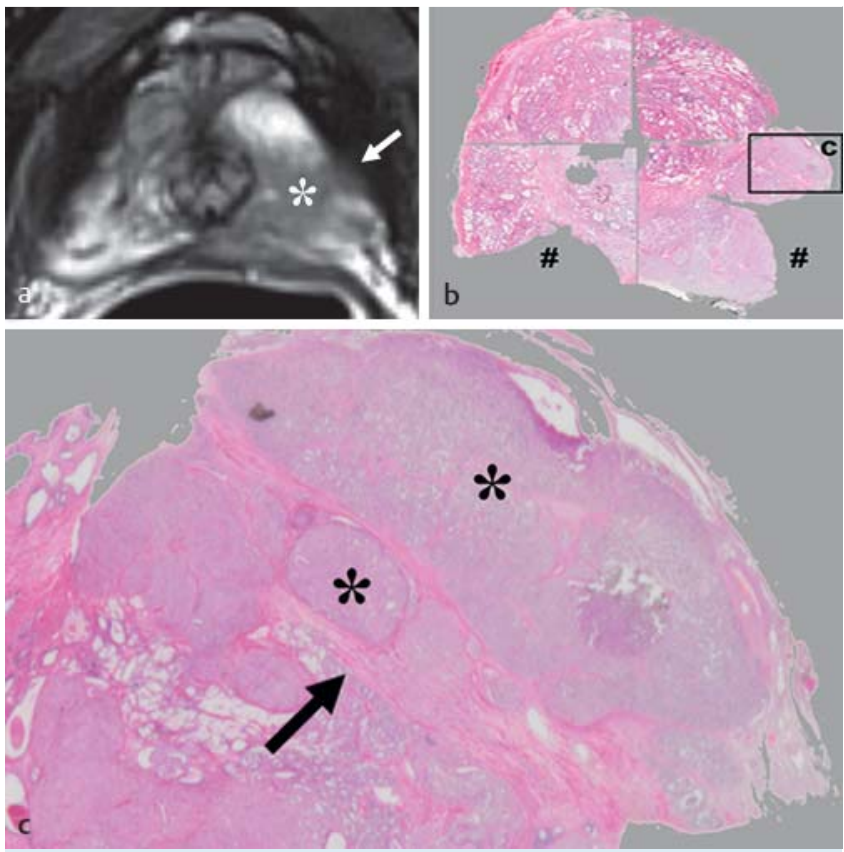

Fig. 3 69-year-old patient with a PSA level of $8.4 \mathrm{ng} / \mathrm{ml}$ and GS $8(4+4)$ carcinoma. a: axial MRI with hypointense T2w signal (asterisk) of the left peripheral zone. The prostate capsule is obscured and capsular bulging is visible. b: corresponding reconstruction of perpendicular histological section of the specimen after radical prostatectomy. Dorsolateral edges (number) are missing because of prior frozen section analysis (see text and - Fig. 1) c: magnified area from b showing capsular thickening (arrow) and extracapsular tumor growth (asterisks) into the periprostatic fat (stage pT3a).

Abb. 3 69-jähriger Patient mit PSA-Serumlevel von $8,4 \mathrm{ng} / \mathrm{ml}$ und GS 8 $(4+4)$ PCa. a: Axiales MRT mit Nachweis einer T2w-hypointensen Signalveränderung (Sternchen) der apikal linken peripheren Zone mit Kontakt zur irregulär vorgewölbten Prostatakapsel auf korrespondierender Höhe. b: Korrespondierendes histopathologisches Schnittpräparat nach radikaler Prostatektomie. Dorsolaterale Defektareale beidseits (Raute) aufgrund der intraoperativen Schnellschnittdiagnostik (siehe Text und $\boldsymbol{A}$ Abb. 1). c: Die Vergrößerung aus b zeigt eine irreguläre Verbreiterung der Prostatakapsel (Pfeil) mit nach extrakapsulär, in das periprostatische Fettgewebe wachsenden Tumoranteilen (Asterisks) (pT3a Stadium).

Table 2 Extracapsular extension (ECE) of prostate cancer per patient.

Tab.2 Patientenbasierte Analyse eines extrakapsulären Tumorwachstums.

\begin{tabular}{|c|c|c|c|c|c|c|}
\hline \multirow{2}{*}{$\begin{array}{l}\text { ECE per patient } \\
\text { MRI }\end{array}$} & & \multicolumn{2}{|c|}{ histopathology } & \multirow[t]{2}{*}{ sensitivity } & \multirow[t]{2}{*}{ specificity } & \multirow[t]{2}{*}{ accuracy } \\
\hline & & + & - & & & \\
\hline \multirow[t]{2}{*}{ reader $\mathrm{A}$} & + & 9 & 7 & \multirow{2}{*}{$\begin{array}{c}90 \% \\
(9 / 10)\end{array}$} & \multirow{2}{*}{$\begin{array}{c}74 \% \\
(20 / 27)\end{array}$} & \multirow{2}{*}{$\begin{array}{c}78 \% \\
(29 / 37)\end{array}$} \\
\hline & - & 1 & 20 & & & \\
\hline \multirow[t]{2}{*}{ reader $B$} & + & 8 & 5 & \multirow{2}{*}{$\begin{array}{c}80 \% \\
(8 / 10)\end{array}$} & \multirow{2}{*}{$\begin{array}{c}82 \% \\
(22 / 27)\end{array}$} & \multirow{2}{*}{$\begin{array}{c}81 \% \\
(30 / 37)\end{array}$} \\
\hline & - & 2 & 22 & & & \\
\hline
\end{tabular}

metry of the neurovascular bundle), 1.6/1.6 (obliteration of the rectoprostatic angle), 3.9/4.2 (irregular bulging of the prostatic contour), 3.1/3.1 (low signal intensity in the rectoprostatic fat) and 2.2/1.6 (overt extracapsular cancer). 

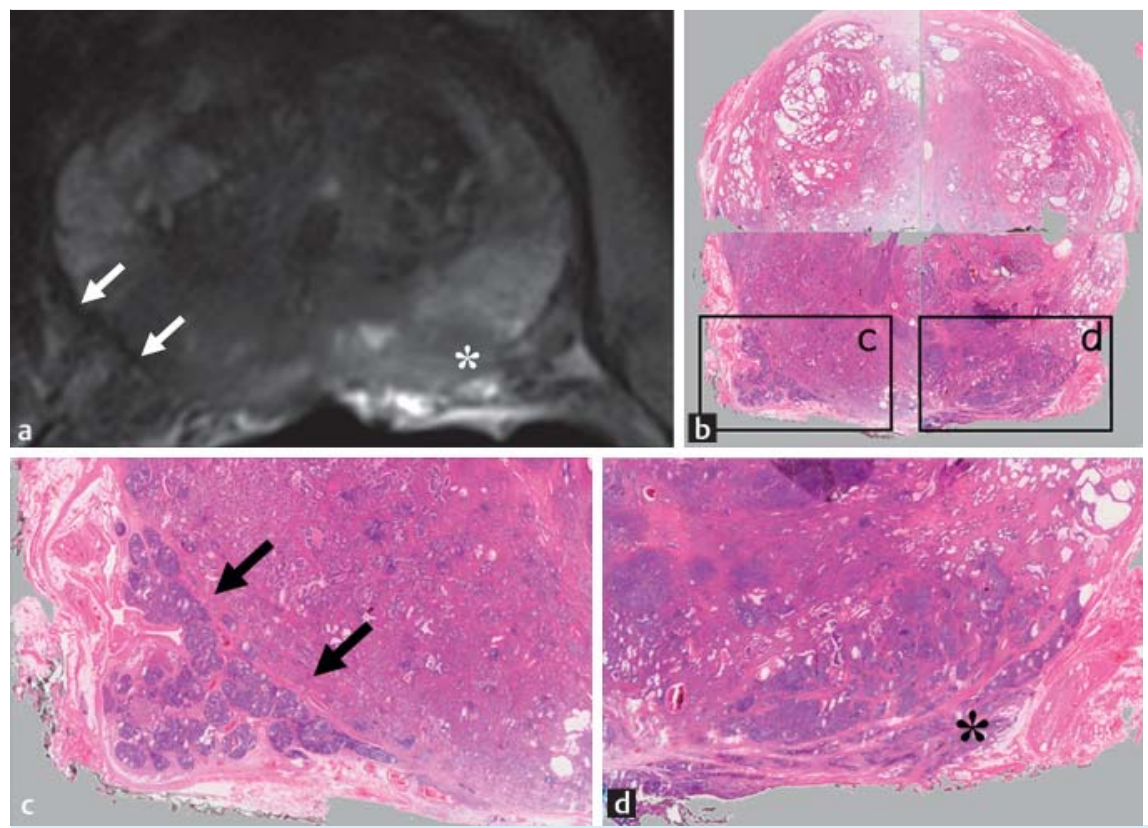

Fig. 4 66-year-old man with a PSA level of $47 \mathrm{ng} / \mathrm{ml}$ and GS $9(4+5)$ carcinoma. a: para-axial T2w image at the level of the mid-prostate with an area of low signal intensity in the right dorsolateral peripheral zone with clearly visible prostate capsule and regularly shaped neurovascular bundle (arrows). T2w hypointense lesion (asterisk) is visible in the left peripheral zone with interruption of capsule signal and hypointense triangular area in the periprostatic fat. $\mathbf{b}$ : corresponding reconstruction of perpendicular histological section of the specimen after radical prostatectomy. c: well-defined prostate capsule (arrows) and regularly shaped neurovascular bundle on the right. d: extensive tumor invasion (asterisk) into the periprostatic fat on the left.
Abb.4 66-jähriger Mann mit PSA-Serumlevel von $47 \mathrm{ng} / \mathrm{ml}$ und GS 9 (4 + 5) PCa. a: Para-axiales T2w-Bild auf Höhe des mittleren Prostatadrittels mit einem Nachweis hypointensen Signalveränderung der dorsolateralen peripheren Zone rechts bei scharf abgrenzbarer Prostatakapsel und regelrecht konfiguriertem neurovaskulären Bündel rechts (Pfeile). Auf korrespondierender Höhe Nachweis einer T2w-hypointensen Signalveränderung (Sternchen) der dorsolateralen peripheren Zone links mit Kontinuitätsunterbrechung der Prostatakapsel und dreieckig hypointenser Signalveränderung im periprostatisches Fett auf korrespondierender Höhe. b: Korrespondierendes histopathologisches Schnittpräparat nach radikaler Prostatektomie. c: Nachweis einer glatt konturierten Prostatakapsel dorsolateral rechts (Pfeile) mit regelrecht konfiguriertem neurovaskulären Bündel. d: Ausgedehnte Tumorinfiltration (Asterisk) in das periprostatische Fettgewebe auf der linken Seite.
Table 3 Seminal vesicle invasion (SVI) per region.

Tab. 3 Regionenbasierte Analyse einer Samenblaseninfiltration.

\begin{tabular}{|c|c|c|c|c|c|c|}
\hline \multirow{2}{*}{$\begin{array}{l}\text { SVI per region } \\
\text { MRI }\end{array}$} & & \multicolumn{2}{|c|}{ histopathology } & \multirow[t]{2}{*}{ sensitivity } & \multirow[t]{2}{*}{ specificity } & \multirow[t]{2}{*}{ accuracy } \\
\hline & & + & - & & & \\
\hline \multirow[t]{2}{*}{ reader $A$} & + & 7 & 3 & $88 \%$ & $95 \%$ & $95 \%$ \\
\hline & - & 1 & 63 & $(7 / 8)$ & $(63 / 66)$ & $(70 / 74)$ \\
\hline \multirow[t]{2}{*}{ reader B } & + & 7 & 1 & $88 \%$ & $98 \%$ & $97 \%$ \\
\hline & - & 1 & 65 & (7/8) & $(65 / 66)$ & $(72 / 74)$ \\
\hline
\end{tabular}

Table 4 Seminal vesicle invasion (SVI) per patient.

Tab. 4 Patientenbasierte Analyse einer Samenblaseninfiltration.

\begin{tabular}{|c|c|c|c|c|c|c|}
\hline \multirow{2}{*}{$\begin{array}{l}\text { SVI per patient } \\
\text { MRI }\end{array}$} & & \multicolumn{2}{|c|}{ histopathology } & \multirow[t]{2}{*}{ sensitivity } & \multirow[t]{2}{*}{ specificity } & \multirow[t]{2}{*}{ accuracy } \\
\hline & & + & - & & & \\
\hline \multirow[t]{2}{*}{ reader $A$} & + & 4 & 2 & $80 \%$ & $96 \%$ & $95 \%$ \\
\hline & - & 1 & 31 & $(4 / 5)$ & $(31 / 32)$ & $(35 / 37)$ \\
\hline \multirow[t]{2}{*}{ reader $B$} & + & 5 & 1 & $100 \%$ & $99 \%$ & $97 \%$ \\
\hline & - & 0 & 31 & $(5 / 5)$ & $(31 / 32)$ & $(36 / 37)$ \\
\hline
\end{tabular}

Table 5 Detection of extracapsular extension (ECE) and seminal vesicle invasion (SVI) without and with correction for "alternative neighbors".

Tab. 5 Detektion eines kapselüberschreitenden Tumorwachstums (ECE) sowie einer Samenblaseninfiltration (SVI) ohne bzw. mit Berücksichtigung „alternativer Nachbarregionen“.

\begin{tabular}{|lcccccc|} 
& \multicolumn{3}{c}{ reader A } & \multicolumn{3}{c}{ reader B } \\
\hline ECE & $\begin{array}{l}\text { sensi- } \\
\text { tivity }\end{array}$ & $\begin{array}{c}\text { speci- } \\
\text { ficity }\end{array}$ & $\begin{array}{c}\text { accu- } \\
\text { racy }\end{array}$ & $\begin{array}{c}\text { sensi- } \\
\text { tivity }\end{array}$ & $\begin{array}{c}\text { speci- } \\
\text { ficity }\end{array}$ & $\begin{array}{c}\text { accu- } \\
\text { racy }\end{array}$ \\
\hline uncorrected & $71 \%$ & $87 \%$ & $86 \%$ & $47 \%$ & $92 \%$ & $89 \%$ \\
\hline corrected & $93 \%$ & $95 \%$ & $92 \%$ & $67 \%$ & $95 \%$ & $93 \%$ \\
\hline SVI & & & & & & \\
\hline uncorrected & $38 \%$ & $95 \%$ & $89 \%$ & $88 \%$ & $98 \%$ & $97 \%$ \\
corrected & $88 \%$ & $95 \%$ & $95 \%$ & $88 \%$ & $98 \%$ & $97 \%$ \\
\hline
\end{tabular}

\section{Discussion}

According to statistical data of the German diagnosis-related group from 2006, two thirds of all patients diagnosed with PCa and under the age of 70 currently undergo radical prostatectomy [15]. This type of surgery carries the risk of damage to blood vessels and nerves that are responsible for urinary continence and erectile function, two important factors with regard to the patient's quality of life [16]. Only patients with organ-confined dis- 
eases are eligible for surgical approaches sparing these sensitive structures [13]. It is therefore important to accurately stage PCa before radical prostatectomy, in particular with respect to extracapsular extension (pT3 stage). Diagnostic tools like digital rectal examination, PSA measurements, systematic TRUS-guided prostate biopsies, and meta-data in the form of nomograms [1] provide some clues to the local stage [13], but are often poorly reliable. An accurate determination of the tumor extent before radical prostatectomy, however, is practically impossible with these techniques [1]. The clinical benefit of preoperative MRI of the prostate is discussed controversially. Although MRI is widely accepted as the most reliable method for the local staging of PCa [1], some authors argue that it has little influence on therapeutic decision making [17].

The presented MRI results are in good agreement with two studies of the staging accuracy of endorectal 3 T MRI $[8,18]$. Our analysis of 222 regions revealed sensitivities of $67 \%$ and $93 \%$ for the individual readers (mean $80 \%$ ) and a mean specificity of $94 \%$. In 256 individual regions, Fütterer et al. reported mean values of $85 \%$ (sensitivity) and 99\% (specificity) for two experienced readers and of $55 \%$ and $94 \%$ for one less experienced reader, respectively [18]. Heijmink et al. included 644 prostate segments and obtained sensitivities of $39-58 \%$ and specificities of $79-91 \%$ for a total of 4 readers with different levels of expertise [8]. With respect to the performance per patient, the above authors reported excellent specificities (>90\%) for all readers. The corresponding sensitivity largely depended on the individual experience with endorectal 3 T MRI diagnosis showing good performance for advanced readers $(73-88 \%)$ and poor results for less experienced readers $(13-50 \%)[8,18]$.

In our study, both readers reached good sensitivities (80\% and $90 \%$ ) and fair specificities (74\% and $82 \%$ ) for ECE detection per patient. In contrast to the results of Heijmink et al., where only T2w images were inspected, our readers had access to the results of diffusion-weighted, contrast-enhanced and MR-spectroscopic imaging as well. Although the impact of functional information on staging accuracy was beyond the aim of this study, we believe that the specificities without such information would have been lower. False-positive results from post-biopsy hemorrhage and inflammation could be ruled out by a systematical correlation of T2w with DWI and DCEI images. In two patients with confirmed ECE, 36 and 41 days after TRUS-guided biopsy, post-biopsy hemorrhage could be detected by a low $\mathrm{T} 2 \mathrm{w}$ signal in combination with an increased precontrast $\mathrm{T} 1 \mathrm{w}$ finding. The more experienced reader correctly related the signal changes to the TRUS biopsy and also detected extracapsular tumor growth near the respective regions. In one patient, hypointense $\mathrm{T} 2 \mathrm{w}$ changes at the dorsolateral midgland level with corresponding high signals on $\mathrm{T} 1 \mathrm{w}$ images were interpreted as post-biopsy hemorrhage without detecting capsule infiltration by the less experienced reader. Fütterer et al. have previously reported that the combined use of T2w and dynamic contrast-enhanced MR images may significantly improve staging performance, in particular for less experienced readers [19]. Therefore, we also believe that a further inclusion of DCEI data will generally help to draw the attention to cancerous areas.

These preliminary results suggest that the staging accuracy of endorectal MRI is not necessarily low for readers with little experience in endorectal $3 \mathrm{~T}$ MRI. It should be noted, however, that the number of patients with extracapsular extension was relatively small here, which compromises the statistical power of the re- ported values, in particular the specificity. More confident findings need to be obtained from larger study groups.

Minimal technical requirements and potential clinical benefit of MRI examinations for PCa staging are still discussed controversially. While a number of studies at $1.5 \mathrm{~T}$ have clearly shown a better staging performance with endorectal imaging, the variability between reported $1.5 \mathrm{~T}$ results is generally significant ( $\bullet$ Table 6). Researchers also come to different conclusions depending on the individual risk of the patient $[5,9,11,22]$. Roethke et al., for example, have recently found the benefit of presurgical endorectal MRI to be more pronounced in patients with a higher risk of pathologic T3 disease, in particular for intermediate and high-risk PCa. In these patients, the neurovascular bundle could potentially be spared during surgery if the disease is confined to the organ [22]. At the same time, Cornud and coworkers have stressed the need for highly specific local staging for such patients to ensure that they are not excluded from curative surgical treatment [11]. For patients with low-risk PCa, Cornud et al. see a benefit of higher image resolution in detecting even subtle extracapsular tumor growth (high sensitivity) [11] We agree that false-negative results should be avoided in these patients to refer them to timely treatment instead of keeping them under active surveillance, for example. In that respect, however, our results at $3 \mathrm{~T}$ do not provide further evidence because none of our low-risk patients showed subtle extracapsular tumor growth. We believe that the higher signal-to-noise ratio makes endorectal imaging the preferred option, even at $3 \mathrm{~T}$, although care must be taken to not misidentify subtle changes as potential T3 disease (false positives). The benefit for staging is also suggested by a $3 \mathrm{~T}$ study by Heijmink et al., who observed better performance with endorectal coils reaching sensitivities and specificities in the $70-100 \%$ range [8].

- Table 6 gives an overview of studies on the local PCa staging accuracy of MRI at different field strengths both with and without the use of an endorectal coil. Owing to the large variety of study conditions, in particular with respect to patient groups, readers and methodology, it is generally difficult to evaluate the results independently. For $3 \mathrm{~T}$ studies without an endorectal coil, however, it can be observed that either the sensitivity $[8,20,23]$ or specificity was found to be below $80 \%$ [6] while both values were higher than $80 \%[8,18]$ in two studies with an endorectal coil, at least for experienced prostate MRI readers (3 years, 250 cases). The good local staging accuracy of 3 T MRI with an endorectal coil, with sensitivities and specificities for ECE and SVI detection largely above $80 \%$, is confirmed in this study.

This work was generally limited by the retrospective design and the fact that both readers knew that patients had biopsy-proven PCa and were scheduled for prostatectomy at our Urology Department. Like similar studies ( $\bullet$ Table 6 ), our results might not be representative for the general patient population because they were obtained on a limited number of patients at a single institution. The choice of a consecutive patient group and the relatively low prevalence of locally advanced disease resulted in 10 positive patients only, so that the reported values for sensitivity and specificity should be interpreted with care. More refined regional analysis, where the entire prostate is divided into 16 or even 27 segments and whole-mount step sections serving the reference standard, are generally preferable to not miss locally advanced disease in other regions. In our study, however, the simpler approach turned out to be sufficient for analysis, because extracapsular extension was actually observed in these six key regions only with slight extension into adjacent sectors. 
Table 6 Comparative overview of the accuracy of MRI for the local staging of prostate cancer.

Tab. 6 Vergleichende Übersicht zur Genauigkeit der MRT für das lokale Staging des Prostatakarzinoms.

\begin{tabular}{|c|c|c|c|c|c|c|c|c|c|c|c|}
\hline & & & & & & & ECE & & & SVI & \\
\hline & $\begin{array}{c}\text { field } \\
\text { strength }\end{array}$ & $\begin{array}{l}\text { number of } \\
\text { patients }\end{array}$ & $\begin{array}{l}\text { endo- } \\
\text { rectal } \\
\text { coil }\end{array}$ & $\begin{array}{c}\text { phased-array } \\
\text { coil }\end{array}$ & $\begin{array}{l}\text { reader's experi- } \\
\text { ence in years } \\
\text { (number } \\
\text { of exams) }\end{array}$ & $\begin{array}{l}\text { sens } \\
(\%)\end{array}$ & $\begin{array}{c}\text { spec } \\
(\%)\end{array}$ & $\begin{array}{l}\text { acc } \\
(\%)\end{array}$ & $\begin{array}{l}\text { sens } \\
(\%)\end{array}$ & $\begin{array}{c}\text { spec } \\
(\%)\end{array}$ & $\begin{array}{l}\text { acc } \\
(\%)\end{array}$ \\
\hline Beyersdorff 2005 [7] & $1.5 \mathrm{~T}$ & 24 & $x$ & $x$ & - & - & - & 73 & - & - & - \\
\hline \multirow[t]{2}{*}{ Fütterer 2006 [24] } & $1.5 \mathrm{~T}$ & 76 & & $x$ & $10(650)$ & 50 & 72 & 63 & 50 & 80 & 76 \\
\hline & & & $x$ & $x$ & $10(650)$ & 57 & 96 & 80 & 90 & 99 & 98 \\
\hline Torricelli 2006 [20] & $1.5 \mathrm{~T}$ & 29 & $\mathrm{x}$ & & - & 83 & 90 & - & - & - & - \\
\hline \multirow[t]{2}{*}{ Bloch 2007 [21] } & $1.5 \mathrm{~T}$ & 32 & $\mathrm{x}$ & $x$ & $15(1300)$ & 82 & 95 & 96 & 100 & 100 & 100 \\
\hline & & & $x$ & $\mathrm{x}$ & $4(500)$ & 91 & 95 & 95 & 100 & 100 & 100 \\
\hline Chandra 2007 [26] & $1.5 \mathrm{~T}$ & 38 & $x$ & $x$ & - & 69 & 82 & 76 & 60 & 100 & 95 \\
\hline \multirow[t]{3}{*}{ Graser 2007 [27] } & $1.5 \mathrm{~T}$ & 106 & $x$ & $x$ & $(800)$ & 91 & 78 & 92 & - & - & - \\
\hline & & & $x$ & $x$ & $(600)$ & 85 & 83 & 86 & - & - & - \\
\hline & & & $x$ & $x$ & $(400)$ & 88 & 80 & 83 & - & - & - \\
\hline \multirow[t]{2}{*}{ Latchamsetty 2007 [31] } & $1.5 \mathrm{~T}$ & 40 & $x$ & $x$ & - & 31 & 71 & 53 & 22 & 100 & 80 \\
\hline & & & $\mathrm{x}$ & $x$ & - & 65 & 78 & 73 & 20 & 94 & 85 \\
\hline Park 2007 [6] & $1.5 \mathrm{~T}$ & 54 & $x$ & & - & 71 & 73 & 72 & 75 & 92 & 91 \\
\hline Zhang 2007 [2] & $1.5 \mathrm{~T}$ & 110 & $x$ & $\mathrm{x}$ & - & 55 & 99 & 91 & 80 & 100 & 99 \\
\hline Tan 2008 [4] & $1.5 \mathrm{~T}$ & 32 & $x$ & $x$ & - & 14 & 94 & 59 & - & - & - \\
\hline \multirow[t]{2}{*}{ Lee 2010 [28] } & $1.5 \mathrm{~T}$ & 44 & & $x$ & - & 29 & 90 & - & 50 & 92 & - \\
\hline & & & $x$ & & - & 32 & 96 & - & 50 & 92 & - \\
\hline Park 2010 [29] & $1.5 \mathrm{~T}$ & 54 & $x$ & $x$ & - & 50 & 83 & 78 & 75 & 92 & 81 \\
\hline \multirow[t]{2}{*}{ Ruprecht 2011 [30] } & $1.5 \mathrm{~T}$ & 46 & $x$ & $x$ & 15 & 78 & 93 & - & - & - & - \\
\hline & & & & & 5 & 33 & 71 & - & - & - & - \\
\hline \multirow[t]{2}{*}{ Renard-Penna 2011 [3] } & $1.5 \mathrm{~T}$ & 100 & & $\mathrm{x}$ & 7 & 94 & - & 81 & 100 & - & - \\
\hline & & & & $x$ & 0.5 & 92 & - & 44 & 100 & - & - \\
\hline Roethke 2012 [22] & $1.5 \mathrm{~T}$ & 385 & $\mathrm{x}$ & $\mathrm{x}$ & $\begin{array}{r}4-14 \\
(300-1,000)\end{array}$ & 42 & 92 & - & - & - & - \\
\hline Beyersdorff 2005 [7] & $3.0 \mathrm{~T}$ & 24 & & $x$ & - & - & - & 73 & - & - & - \\
\hline \multirow[t]{3}{*}{ Fütterer 2006 [18] } & $3.0 \mathrm{~T}$ & 32 & $x$ & $x$ & $10(700)$ & 88 & 96 & 94 & 100 & 100 & 100 \\
\hline & & & $x$ & $x$ & $3(250)$ & 88 & 96 & 94 & 100 & 100 & 100 \\
\hline & & & $x$ & $\mathrm{x}$ & $0.5(30)$ & 50 & 92 & 81 & 100 & 100 & 100 \\
\hline Torricelli 2006 [20] & $3.0 \mathrm{~T}$ & 29 & & $x$ & - & 75 & 90 & - & - & - & - \\
\hline \multirow[t]{8}{*}{ Heijmink 2007 [8] } & $3.0 \mathrm{~T}$ & 46 & & $x$ & $4(400)$ & 7 & 100 & 70 & - & - & - \\
\hline & & & & $x$ & $2(150)$ & 7 & 94 & 65 & - & - & - \\
\hline & & & & $\mathrm{x}$ & $0.25(20)$ & 7 & 100 & 70 & - & - & - \\
\hline & & & & $x$ & $0.25(20)$ & 13 & 81 & 59 & - & - & - \\
\hline & & & $\mathrm{x}$ & & $4(400)$ & 80 & 100 & 93 & - & - & - \\
\hline & & & $x$ & & $2(150)$ & 73 & 97 & 89 & - & - & - \\
\hline & & & $x$ & & $0.25(20)$ & 13 & 94 & 67 & - & - & - \\
\hline & & & $x$ & & $0.25(20)$ & 33 & 94 & 74 & - & - & - \\
\hline Park 2007 [6] & $3.0 \mathrm{~T}$ & 54 & & $x$ & - & 81 & 67 & 72 & 50 & 100 & 98 \\
\hline Augustin 2009 [23] & $3.0 \mathrm{~T}$ & 27 & & $x$ & - & 67 & 100 & 85 & - & - & - \\
\hline \multirow[t]{2}{*}{ current study 2013} & $3.0 \mathrm{~T}$ & 37 & $x$ & $x$ & $9(40)$ & 90 & 74 & 78 & 80 & 96 & 95 \\
\hline & & & $x$ & $x$ & $4(15)$ & 80 & 82 & 81 & 100 & 99 & 97 \\
\hline
\end{tabular}

$E C E=$ extracapsular extension, $S V I=$ seminal vesicle invasion, Sens = sensitivity, Spec = specificity, Acc = accuracy

$\mathrm{ECE}=$ Extrakapsuläres Tumorwachstum, SVI = Samenblaseninfilration. Sens = Sensitivität, Spec = Spezifität, Acc = Genauigkeit

In conclusion, these preliminary results provide additional evidence that the local staging of PCa at $3 \mathrm{~T}$ with an endorectal coil is a highly reliable technique to noninvasively detect extraprostatic tumor growth. More extensive studies will be needed to provide more reliable estimates of the predictive power of endorectal $3 \mathrm{~T}$ MRI and also further assess the impact of reader experience.

\section{Clinical relevance of study}

- Endorectal MRI at $3 \mathrm{~T}$ provides high accuracy for the detection of pT3 stage prostate cancer.

- MRI may potentially be an alternative staging method to more invasive techniques such as ultrasound-guided biopsy.

- Endorectal $3 \mathrm{~T}$ MRI assessment of extracapsular tumor growth may be particularly helpful for patients scheduled for nerve-sparing surgical treatment. 


\section{References}

1 Hoeks CMA, Barentsz JO, Hambrock T et al. Prostate cancer: Multiparametric MR imaging for detection, localization, and staging. Radiology $2011 ; 261: 46-66$

2 Zhang JQ Loughlin KR, Zou KH et al. Role of endorectal coil magnetic resonance imaging in treatment of patients with prostate cancer and in determining radical prostatectomy surgical margin status: Report of a single surgeon's practice. Urology 2007; 69: 1134-1137

3 Renard-Penna R, Rouprêt M, Comperat E et al. Accuracy of high resolution (1.5 tesla) pelvic phased array magnetic resonance imaging (MRI) in staging prostate cancer in candidates for radical prostatectomy: Results from a prospective study. Urol Oncol 2013; 31: 448-454

4 Tan JSP, Thng CH, Tan PH et al. Local experience of endorectal magnetic resonance imaging of prostate with correlation to radical prostatectomy specimens. Ann Acad Med Singapore 2008; 37: 40-43

5 Fütterer JJ, Barentsz JO, Heijmink SWTPJ. Value of 3-T magnetic resonance imaging in local staging of prostate cancer. Top Magn Reson Imaging 2008; 19: 285-289

6 Park BK, Kim B, Kim CK et al. Comparison of phased-array 3.0-T and endorectal 1.5-T magnetic resonance imaging in the evaluation of local staging accuracy for Prostate Cancer. J Comput Assist Tomogr 2007; 31: $534-538$

7 Beyersdorff $D$, Taymoorian $K$, Knosel $T$ et al. MRI of prostate cancer at 1.5 and 3.0 T: Comparison of image quality in tumor detection and staging. Am J Roentgenol Am J Roentgenol 2005; 185: 1214-1220

8 Heijmink SWTPJ, Fütterer JJ, Hambrock T et al. Prostate Cancer: Bodyarray versus endorectal coil MR imaging at $3 \mathrm{~T}$ - comparison of image quality, localization, and staging performance. Radiology 2007; 244: $184-195$

9 Tempany CM, Zhou X, Zerhouni EA et al. Staging of prostate cancer: results of Radiology Diagnostic Oncology Group project comparison of three MR imaging techniques. Radiology 1994; 192: 47-54

$10 \mathrm{Yu}$ KK, Hricak H, Alagappan R et al. Detection of extracapsular extension of prostate carcinoma with endorectal and phased-array coil MR imaging: multivariate feature analysis. Radiology 1997; 202: 697-702

11 Cornud F, Rouanne M, Beuvon F et al. Endorectal 3D T2-weighted 1mmslice thickness MRI for prostate cancer staging at 1.5Tesla: should we reconsider the indirects signs of extracapsular extension according to the D'Amico tumor risk criteria? Eur J Radiol 2012; 81: e591 - e597

12 Soylu FN, Peng Y, Jiang $Y$ et al. Seminal vesicle invasion in prostate cancer: evaluation by using multiparametric endorectal MR imaging. Radiology 2013; 267: 797-806

13 Heidenreich A, Bellmunt J, Bolla $M$ et al. EAU guidelines on prostate cancer. Part 1: screening, diagnosis, and treatment of clinically localised disease. Eur Urol 2011; 59: 61-71

14 Turkbey B, Pinto PA, Mani H et al. Prostate Cancer: Value of multiparametric MR imaging at $3 \mathrm{~T}$ for detection - histopathologic correlation. Radiology 2010; 255: 89-99

15 Statistics DRG. Diagnosis related groups, diagnoses and procedures of full-time patients in hospitals "Fallpauschalenbezogene Krankenhausstatistik". Information System of (German) Federal Health Report, 2006. Available via www.gbe-bund.de
16 Stolzenburg JU, Andrikopoulos O, Kallidonis P et al. Evolution of endoscopic extraperitoneal radical prostatectomy (EERPE): technique and outcome. Asian J Androl 2012: 278 - 284

17 Brajtbord JS, Lavery HJ, Nabizada PaceF et al. Endorectal magnetic resonance imaging has limited clinical ability to preoperatively predict pT3 prostate cancer. BJU Int 2011; 107: 1419-1424

18 Fütterer IJ, Heijmink SWTPJ, Scheenen TWJ et al. Prostate cancer: Loca staging at 3-T endorectal MR imaging - early experience. Radiology 2006; 238: $184-191$

19 Fütterer JJ, Engelbrecht MR, Huisman HJ et al. Staging prostate cancer with dynamic contrast-enhanced endorectal MR imaging prior to radical prostatectomy: experienced versus less experienced readers. Radiology 2005; 237: 541 - 549

20 Torricelli P, Cinquantini F, Ligabue $G$ et al. Comparative evaluation between external phased array coil at $3 \mathrm{~T}$ and endorectal coil at $1.5 \mathrm{~T}$ : preliminary results. J Comput Assist Tomogr 2006; 30: 355-361

21 Bloch BN, Furman-Haran E, Helbich TH et al. Prostate cancer: accurate determination of extracapsular extension with high-spatial-resolution dynamic contrast-enhanced and T2-weighted MR imaging-initial results. Radiology 2007; 245: 176-185

22 Roethke MC, Lichy M, Kniess $M$ et al. Accuracy of preoperative endorectal MRI in predicting extracapsular extension and influence on neurovascular bundle sparing in radical prostatectomy. World J Urol 2013 Epub ahead of print: DOI: $10.1007 / \mathrm{s} 00345-012-0826-0$

23 Augustin H, Fritz GA, Ehammer T et al. Accuracy of 3-Tesla magnetic resonance imaging for the staging of prostate cancer in comparison to the Partin tables. Acta Radiol 2009; 50: 562 -569

24 Fütterer JJ, Engelbrecht MR, Jager GJ et al. Prostate cancer: comparison of local staging accuracy of pelvic phased-array coil alone versus integrated endorectal-pelvic phased-array coils. Eur Radiol 2006; 17: $1055-1065$

25 Bloch BN, Furman-Haran E, Helbich TH et al. Prostate cancer: accurate determination of extracapsular extension with high-spatial-resolution dynamic contrast-enhanced and T2-weighted MR imaging-initial results. Radiology 2007; 245: 176 - 185

26 Chandra RV, Heinze S, Dowling RS et al. Endorectal magnetic resonance imaging staging of prostate cancer. ANZ J Surg 2007; 77: 860 - 865

27 Graser A, Heuck A, Sommer B et al. Per-sextant localization and staging of prostate cancer: correlation of imaging findings with whole-mount step section histopathology. Am J Roentgenol Am J Roentgenol 2007; 188: $84-90$

28 Lee SH, Park KK, Choi KH et al. Is endorectal coil necessary for the staging of clinically localized prostate cancer? Comparison of non-endorectal versus endorectal MR imaging. World J Urol 2010; 28: 667-672

29 Park SY, Kim JJ, Kim TH et al. The role of endorectal magnetic resonance imaging in predicting extraprostatic extension and seminal vesicle invasion in clinically localized prostate cancer. Korean J Urol 2010; 51: $308-312$

30 Ruprecht $O$, Weisser $P$, Bodelle $B$ et al. MRI of the prostate: Interobserver agreement compared with histopathologic outcome after radical prostatectomy. Eur J Radiol 2012; 81: 456 - 460

31 Latchamsetty KC, Borden LS Jr, Porter CR et al. Experience improves staging accuracy of endorectal magnetic resonance imaging in prostate cancer: what is the learning curve? Can J Urol 2007; 14: 3429-3434 